\title{
Téoros
}

Revue de recherche en tourisme

\section{From Romanticism to New Age}

The Evolving Perception of a Church Ruin

\section{Thomas Coomans}

Volume 24, numéro 2, été 2005

Tourisme, religion et patrimoine : nouveaux regards sur une triade ancienne

URI : https://id.erudit.org/iderudit/1071089ar

DOI : https://doi.org/10.7202/1071089ar

Aller au sommaire du numéro

\section{Éditeur(s)}

Université du Québec à Montréal

ISSN

0712-8657 (imprimé)

1923-2705 (numérique)

Découvrir la revue

Citer cet article

Coomans, T. (2005). From Romanticism to New Age: The Evolving Perception of a Church Ruin. Téoros, 24(2), 47-57. https://doi.org/10.7202/1071089ar d'utilisation que vous pouvez consulter en ligne.

https://apropos.erudit.org/fr/usagers/politique-dutilisation/ 


\section{From Romanticism to New Age The Evolving Perception of a Church Ruin}

\section{Thomas Coomans}

By September 1, 1796, the Directoire had decided to dissolve all religious orders in France and the territories under French rule. Hundreds of abbeys, monasteries and convents, with all their lands and goods, became state property. They were sold the following month to raise money in order to avoid state bankruptcy and finance the war effort. Present-day Belgium had been annexed a few years earlier, and its former monastic properties were therefore dissolved and publicly auctioned (Antoine, 1996).

One of them was the Cistercian abbey of Villers, founded in 1146 by St. Bernard and the burial place of several dukes of Brabant ${ }^{\mathbf{1}}$. A French contractor bought the buildings and immediately took steps to turn a profit on his investment. He sold all the building materials he could, i.e., roof slates, windowpanes, structural timber, wood from the stairs and floors, paving stones, lead from the plumbing system, marble from the altars and tombs, carved stones and even the bricks. Lime kilns were built on the site and all of the limestone burnt, including the entire neo-classic facade, which had been erected a few years earlier, at great expense, in front of the medieval facade of the church. Only the rough schist stone of the medieval structures, which had no value at all, remained standing like the dark skeleton of a whale. While most churches in dissolved communities were completely destroyed or recycled, Villers became a ruin - one of the finest ruins of a medieval church on the continent (ill. 1).

The purpose of this article is to examine the evolving perception of an important church ruin. How did a collapsing structure without any economic value or sacred significance gradually become a national monument deemed worthy of care and public funding for its maintenance.

\section{"Black goods of the Church"}

The ownership of former church properties, which had been confiscated as Biens Nationaux, was a crucial question in the early decades of the nineteenth century. As early as 1791 , Pope Pius VI and the bishops had forbidden Catholics to purchase such properties. The Concordat of 1801 between the Church and state did not entirely resolve the question of the rights of the Church to the Biens Nationaux, which the state had sold to private owners. One generation later, as a result of sales, acquisitions, divisions, successions and speculation, it was difficult to know precisely whether a piece of land was or was not a "black good of the Church". Not until 1833, after obtaining substantial compensation, did Belgian bishops convince Pope Gregory XVI to lift the ban and ease the conscience of numerous Catholics. Moreover, private owners were angry about the possible claim of tithes by the Church.

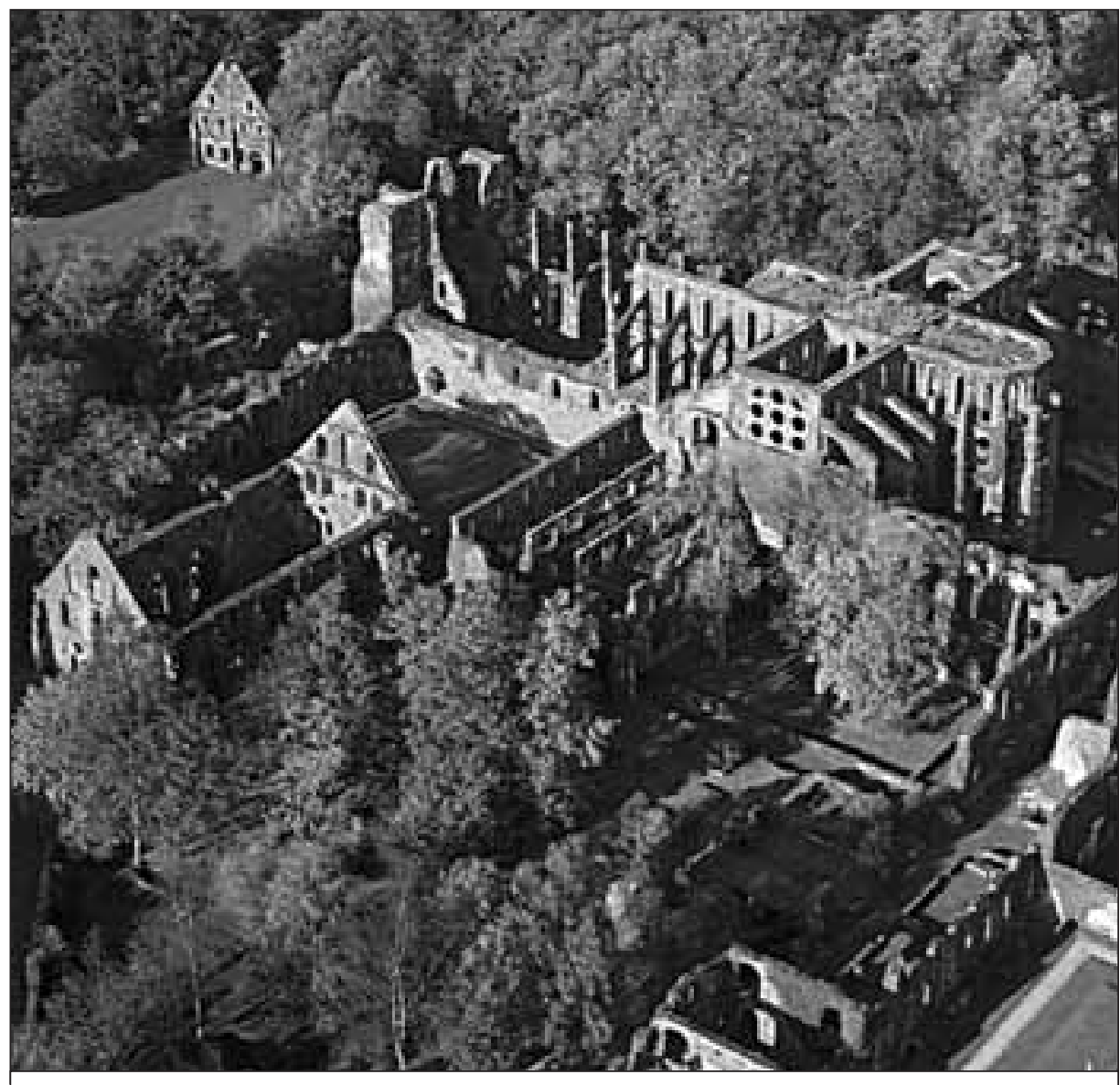

III. 1: Aerial view of the ruins of the abbey of Villers.

Photo: @ Gus Poncin, circa 1965 
However, unlike land, it was obvious that a church building, even one in ruins, was a "black good of the Church". Therefore, most church owners were liberals, who did not believe in the godly maledictions of Catholics. In the early 1830s, successful literature Henry Spelman's History and Fate of Sacrilege (Spelman, 1846), for exampletroubled the consciences of many (Tordoir, 2002:140). As such, it comes as no surprise that privatized churches continued to be demolished instead of reused.

From 1796 to 1893 - nearly a century - the successive private owners of Villers only exploited the buildings' resources. As part of the rising industrial class - the Huart family owned glassworks - they considered the site a diversified investment. They also had a lodge on site and spent a few weeks there in the summer. There are no indications that the last monks of the dispersed community ever tried to buy the site and start a new monastery at Villers, which some communities succeeded to do in other places. As mentioned above, the first assault to the buildings was the work of man. When everything that could be recycled was sold, the valueless structure was abandoned to the elements. Later, as we shall see, the railway and first tourists would give the ruins a new dimension and provide substantial benefits to the owners.

\section{Returning to dust : \\ Ruins as inspiration for Romantic painters and poets}

Ruins in general and those of Villers in particular began to attract interest in the 1820 s. In his Voyage pittoresque, published in 1825 , J ean De Cloet was the first to mention Villers and publish a lithograph of the ruins (1825:100; before 1830:171). Because it was close to Brussels and on a magnificent site, the ruins of Villers attracted romantic artists, painters and drawers as well as writers and poets (Pil, 1993: 79-82;135-139). They belonged to a generation that had not known the abbey at the time of the monks and was confronted with the new industrial society. In the ruins they found a source of melancholy and sorrow, the remains of a glorious age already long past. There, they confronted the limits of their own human condition: aging, decline and death. What had once been a great human endeavor of faith and order had returned to chaos, nature and dust.
Several authors tried to comprehend the reasons for such a disaster. Was it only the barbarism of men or was it a punishment of God?

Au milieu d'une vallé entourée de bois de toutes parts, dans la solitude la plus profonde, gisent de vastes amas de ruines, qu'on prendrait pour celles d'une ville. Ce sont les ruines de l'abbaye de Villers. Des débris d'une architecture splendide; de longues suites de bâtiments effondrés, semblables à ces squelettes qu'abandonne l'incendie; une église toute entière dressant encore dans l'air ses arcs-boutants et ses ogives; de hautes fenêtres où s'épanouissent des trèfles arabes; des cloîtres aux arceaux multipliés, semblent lutter contre la végétation qui les envahit, qui les presse et les étouffe sous un linceul vert et flottant. Rien ne peut rendre la désolation d'un semblable tableau. Nulle part l'ouragan révolutionnaire n'a laissé des traces plus terribles, plus tristement éloquentes. II est impossible de méconnaître le doigt de Dieu dans cet anéantissement providentiel. C'est l'ange de la Mort qui a touché ce monastère de son épée vengeresse. Quel crime devait-il expier? Étaient-ce ses richesse? Son insolent oubli des vertus de son fondateur, de la charité divine, de la pauvreté évangélique, de l'humilité chrétienne? - Ou bien, était-ce que les temps étaient venus, que la destinée était accomplie, et que Dieu, dans ses impénétrables desseins, frappait à la fois l'innocent et le coupable? (Gens, 1849:106-107)

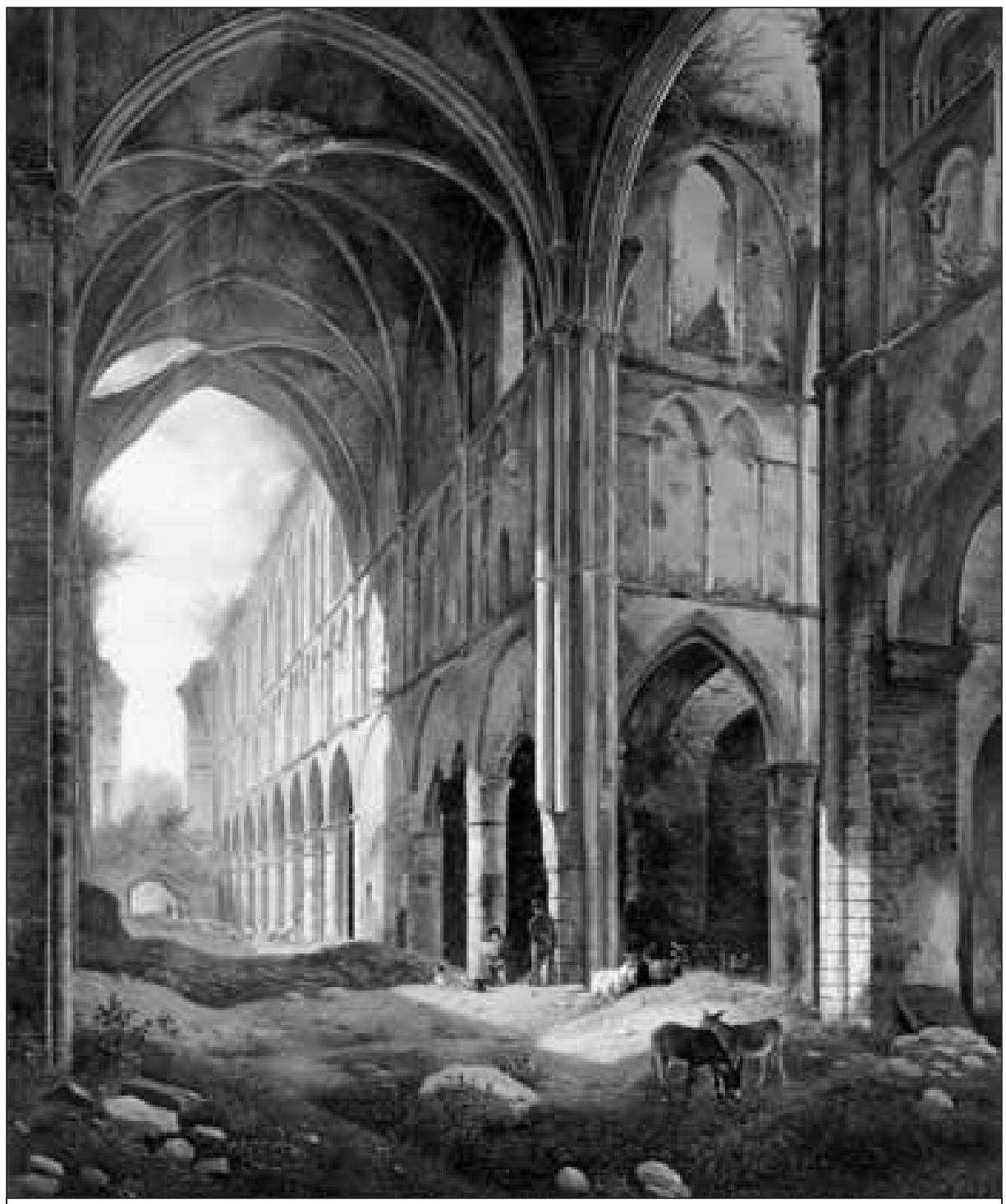

III. 2: Romantic printing of the Ruins of the church of Villers by J ean-Baptiste De J onghe, 1834. Photo: (c) Brussels, Royal Palace, Inv. 356 
The ruins were an inexhaustible source of inspiration. Paintings and lithographs showed violent contrasts of light and depicted mysterious and fantastic forms with entanglements of masonry and vegetation (ill. 2). Novels told of the life of the last monk and the hiding-place of the monastery's treasure, while the first history books, written like chronicles, mixed historical fact and imagined anecdotes (Rodenbach, 1850).

In Belgium, Romanticism developed together with the national identity of the new nation-state - independent as of 1830 - and the rediscovery of the medieval past (Tollebeek, 1998). As a result, Villers became the emblematic example of a religious ruin, like ruined medieval fortresses were for the military past. The smashed and open western façade of the abbey church was used on the titlepage of the standard work Ruines et paysages en Belgique, by Eugène Gens in 1849 (ill. 3). As with the traditional vedute of Antique ruins, a carefree shepherd and his cattle are the silent witnesses to a vanished way of life. It is the silence after the storm of destruction.

The most illustrious visitor of Villers was certainly Victor Hugo (Coomans and Verschaffel, 2003). During his exile in Belgium, between 1861 and 1869, he often visited the ruins of Villers and made some drawings. The monastic prisons of the abbey inspired his fertile imagination, with several lines in Les $M$ iserables referring to the darkness of the Middle Ages and religious obscurantism (Hugo, 1952 [1862]:528-529).

\section{Tourists, railways,} cameras and graffiti

An 1839 article about the picturesque countryside around Brussels declared:

Lecteur fortuné qui avez du temps et de l'argent à dépenser, voulez-vous passer une agréable villégiature? Allez vous nicher pour trois semaines chez le fermier de Villers (...) il vous racontera l'histo ire de ces ruines mieux que je ne pourrais le faire; enfin, le soir, si la lune fait défaut, il allumera dans l'église un beau feu de Saint-J ean, et, assis commodément au haut d'une terrasse, vous aurez la plus éblouissante fantasmagorie qu'il soit possible d'imaginer. Bruxellois, vous avez dans vos environs les ruines de Villers et vous n'y allez pas! Touristes,

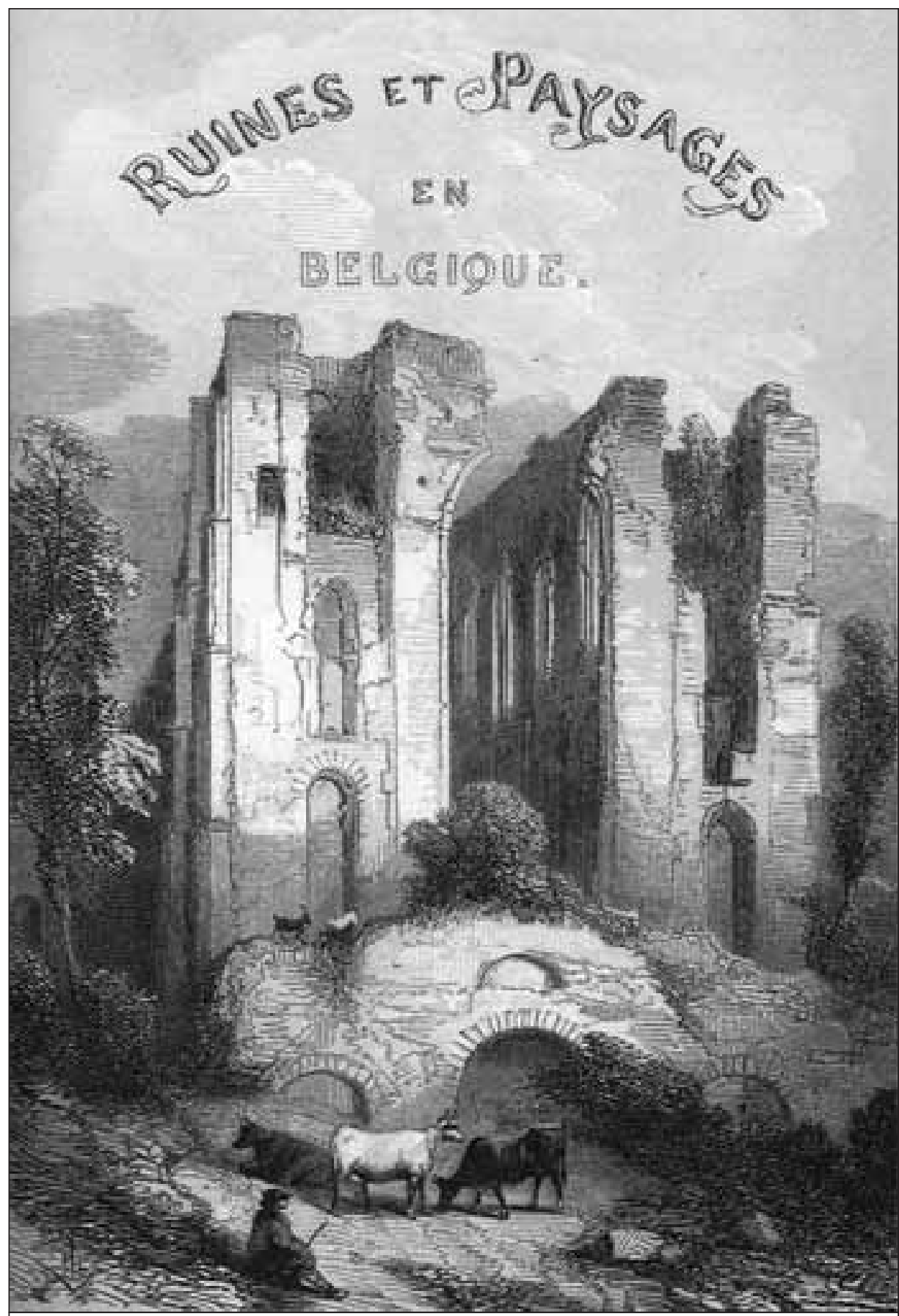

III.3: The ruined church of Villers on the titlepage of Ruines et paysages en Belgique by Eugène Gens, 1849. Photo: Louvain, Library of the Katholieke Universiteit Leuven

vous traversez la Manche pour admirer les vieux prieurés de l'Écosse et vous passez dédaigneusement devant les débris de Villers! Vous me faites pitié, en vérité. (T.J ., 1839-1840: 15)

This would change in the 1850 s, as tourists gradually began to outnumber the Romantic painters and poets. The arrival of the railway had a huge impact on Villers. In 1855, the owner was happy enough to sell a concession to a railway company, which was building a line between the industrial city of Charleroi and the harbor in Antwerp. The line cut through the ruins only 20 meters away from the apse of the church. Some have suggested that this may have been a deliberate decision by the Liberal government to 
make it impossible for the monks to ever return (Bueger-Van Lierde, 2002:12-29). Although there is no proof, this rumor reveals the deep political tensions between Catholics and Liberals and the ideological stakes represented by the ruins, as we will see later. The first consequence of the railway was esthetical: an arched bridge was erected through the former terrace gardens of the abbot and frequent steam trains brought industrial noise and vibration into this place of silence.

The time of the shepherds was definitely over. A new kind of animal invaded the ruins, now 40 minutes from Brussels by train. The first to see the potential for gain was the miller, who turned a part of the old abbey watermill into a restaurant, then, after a fire in 1858, into a hotel-restaurant. He also became the first warden of the ruins and combined ticketing with catering. A kiosk for musicians was erected in the ruins and balls were organized in the summer for members of the bourgeoisie from the capital. Often, parties ended very late and were criticized by those who felt the abbey ruins should be a place of silence, moral austerity and respect for the dead.
With tourism came a new literary genre: the guide or vade-mecum (Willaumez, 2002:4-11) generally composed of a historical and a descriptive section, each containing numerous anecdotes. Along with the railway and tourists, photography arrived at Villers in the mid1850s (Andries and Aerts, 1993:105). The ruins became a favorite subject for photographers. Tourists took hundreds of pictures in the ruins, many of which have become valuable historical sources today (ill. 4).

The great plague brought by tourists was graffiti. Old photographs show walls covered in carved, drawn and written graffiti. In Guerre aux Démolisseurs, first published 1832, Victor Hugo was the very first to denounce vandals who destroyed medieval architecture. Later, when tourists arrived, Hugo rose up against graffiti, a new form of vandalism. In the 1860s, on a wall of the ruins of Villers, he wrote a famous graffiti against the graffiti writers:

\section{Veni, vidi, flevi.}

Ô fats ! sots parvenus, ô pitoyable engeance Qui promenez ici votre sotte ignorance Et votre vanité,

Cessez de conspuer cette admirable ruine

En y bavant vos noms qui, comme une vermine,

Souillent sa majesté!

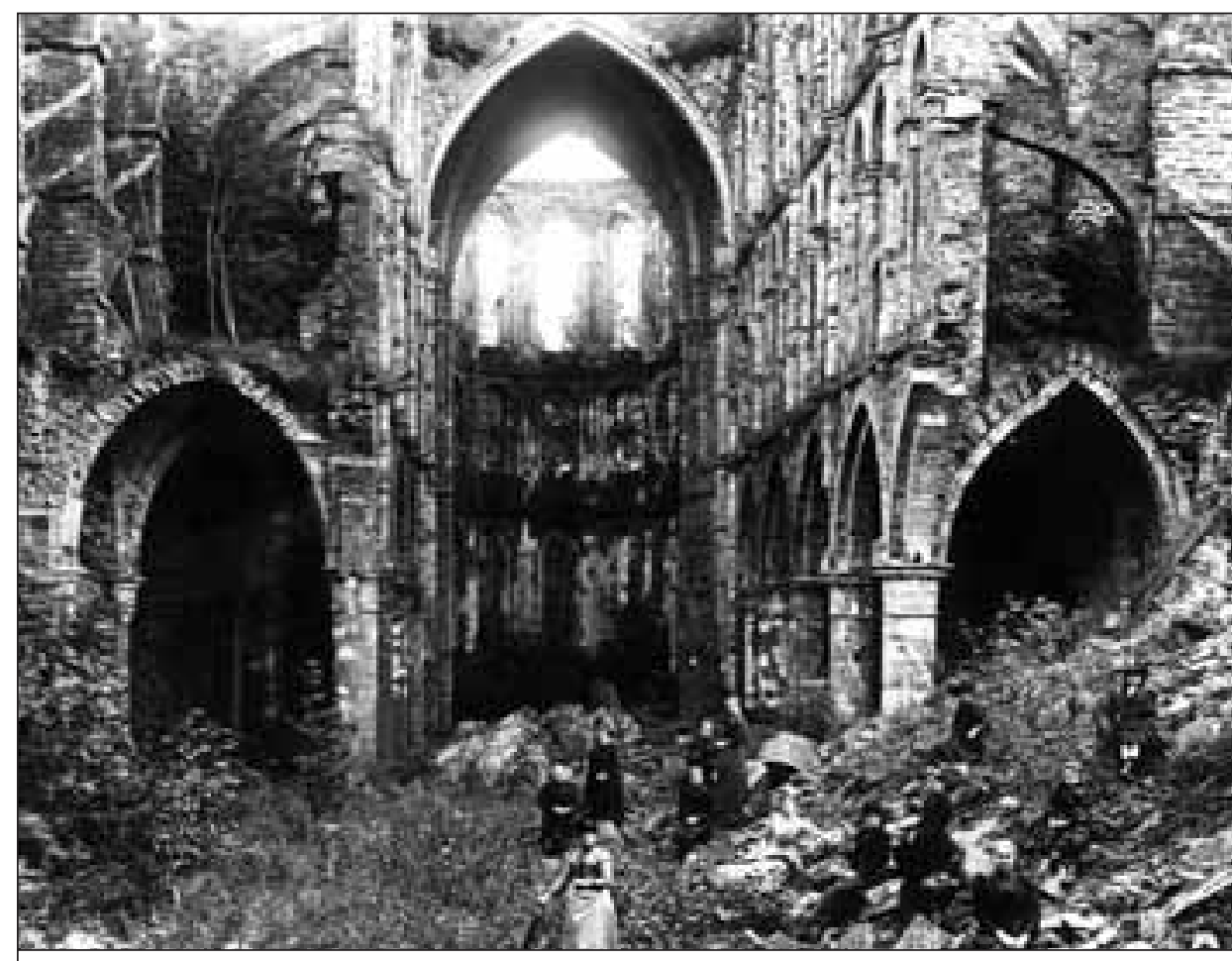

III. 4: Group of tourists in the church of Villers after the collapse, circa 1885.

Photo: @ Brussels, Institut Royal du Patrimoine Artistique, 4728A

\section{Rationalism and archaeology}

From about the mid-nineteenth century, interest in the past became less Romantic and more rational. From a subject for artists, Villers became an object of study for archaeologists and historians. The Royal Commission for Monuments, founded in $1835^{2}$, played a crucial role in the recognition of Belgium's national heritage. Antonin Schayes was a pioneer, writing the first book on medieval architecture in the country. In his Essai sur l'architecture ogivale en Belgique, published in 1840 and recognized by the Belgian Academy of Fine-Arts, Villers received considerable attention (Schayes, 1840: 69-72). But serious historical work on the abbey only began after 1850, and archaeological work, after 1860. In the meantime, the ruins deteriorated quickly under the relentless attacks of weather and nature.

In 1862, the Royal Commission for Monuments asked the government to put architect Émile Coulon (1878: 259-321). in charge of writing of a monograph of the abbey. This ambitious project, inspired by the methodology of Anatole de Baudot and Viollet-le-Duc, would have included drawings of all the buildings. Considering the ruins impossible to restore, the Commission felt it essential to record the buildings' measurements and take casts of the capitals and carved bosses. The Commission's intention was not only to preserve the memory of a lost monument, but also to make a good model of medieval architecture available to the architects in hopes that it would inspire new creations. In the end, the government cancelled the project, and Coulon was forced to limit his ambitions to taking the measurements of the church and publishing an article in the 1878 issue of the journal of the Royal Commission for Monuments. One year earlier, a young architect and archaeologist, Charles Licot, had published an accurate short monograph with reconstruction drawings, which was much more straightforward and became a best seller among tourists (Licot and Lefèvre, 1877, [1883 and 1929]). The owner did not encourage archaeological work in the ruins and forbade excavations of all kinds. Licot therefore bribed the warden and dug with friends by torchlight at night. 
During a stormy night in 1876, a large section of the nave collapsed, underscoring the dramatic condition of the ruin. Flooded and overgrown with weeds, the vaults collapsed one after the other, leaving the flying-buttresses unstable and gradually pushing the walls to their breaking point. The gothic structure was destroyed just as it was built!

Studies attracted scientific attention, and the abbey was considered a national monument worthy of official protection. Under pressure from antiquarian societies and the Royal Commission for Monuments, the government decided to purchase the ruins. The very difficult negotiations with the owner lasted for fifteen years, ending in 1892 when the government decided to expropriate the abbey in the public interest. This decision was not a given, because the liberal Belgian constitution guaranteed property rights. On the one hand, there was no legal basis for declaring the ruins to be of public interest; and on the other, the expropriation would deprive the owner of the income from his tourist business.

\section{Ideology and conservation: Is a restored ruin still a ruin?}

When it became owner, the state immediately decided to undertake urgent conservation work and put architect Charles Licot in charge of the "artistic direction" of the project, while "technical direction" was handled by engineers with the Ministry of Public Works. The records of this extensive project show five phases, corresponding to various changes in the underlying motivations ${ }^{3}$. After the initial cleanup and urgent repairs in 1893-1897 (ill. 5), the rationalistic and the romantic schools alternately fought for their concept of restoration. The debate concerned whether a restored ruin could still be considered as a genuine ruin (Vries, 1999:181-183). But behind the artistic debate, there was an ideological one.

On the one side, there was the position of the engineer Charles Lagasse de Locht, who was both a director general at the Ministry of Public Works and the president of the Royal Commission for Monuments. He had archaeological and historical arguments and would not have hesitated to reconstruct large parts of the medieval buildings, as shown by the building programs for the years 1901-1904. Lagasse was an ultramontane Catholic and one of the promoters

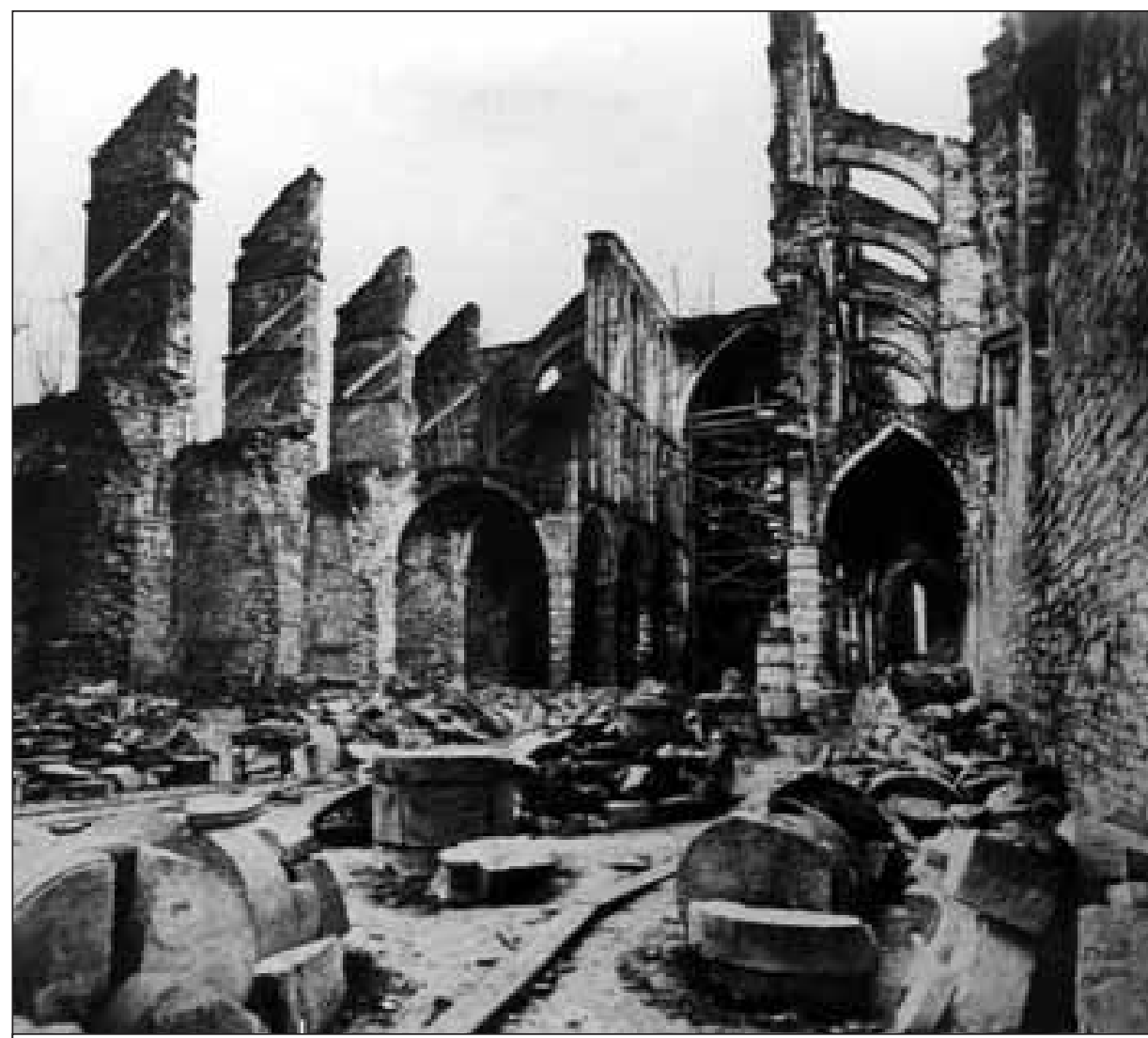

III. 5: The first stage of restoration consisted in cleaning the site and sorting the stones, which could be reused for anastylosis. Nave of the church, December 1893.

Photo: @ Brussels, Institut Royal du Patrimoine Artistique, 126977A

of the neo-gothic style of the St. Luke schools as the Belgian national style. For thirty years, from 1884 to 1914 , homogenous Catholic governments ruled Belgium (De Maeyer, 1988; 2000:19-34). Since Villers was the icon of the monastic past, restoring the ruins was much more than just heritage issue, but a matter of conserving an important part of the Catholic identity. In a way, it was spectacular revenge after a century of ruin and destruction: the abbey, which had been sold by a decision of a French lay government to raise money, would be restored with public money by a Belgian Catholic government.

On the other side, highly polemic papers by Hippolyte Fierens-Gevaert-a professor of aesthetics at the university of Liège and curator of the Royal Museum of Fine Arts at Brussels-defended the "picturesque" point of view, allowing only for conservation of the existing vestiges without any additions, even at the expense of interrupting the work underway and at the risk of creating new ruins. In the French Gazette des Beaux-Arts, Fierens-Gevaert penned a heartfelt cry :
C'est un crime, une profanation! II n'y a donc personne en Belgique parmi les membres du gouvernement et des commissions compétentes pour sentir le profond ridicule qui s'attache à la réunion de ces mots "restauration de ruines"? Une ruine restaurée est-elle encore une ruine? (...) Et ne sait-on pas que l'on détruit la beauté des paysages environnants en se livrant à ces reconstitutions sacrilèges? (Fierens-Gevaert, 1900 :347-349)

For much of the nineteenth century, the destruction of the abbey had been considered "sacrilegious", now the reconstruction was!

Between these positions, Charles Licot $-a$ proponent of Viollet-le-Duc's secular rationalism rather than the Catholic St. Luke movement- steered a middle path, thanks to his archaeological background and sensitivity for the monument. His death in 1903 left the project without artistic direction. 


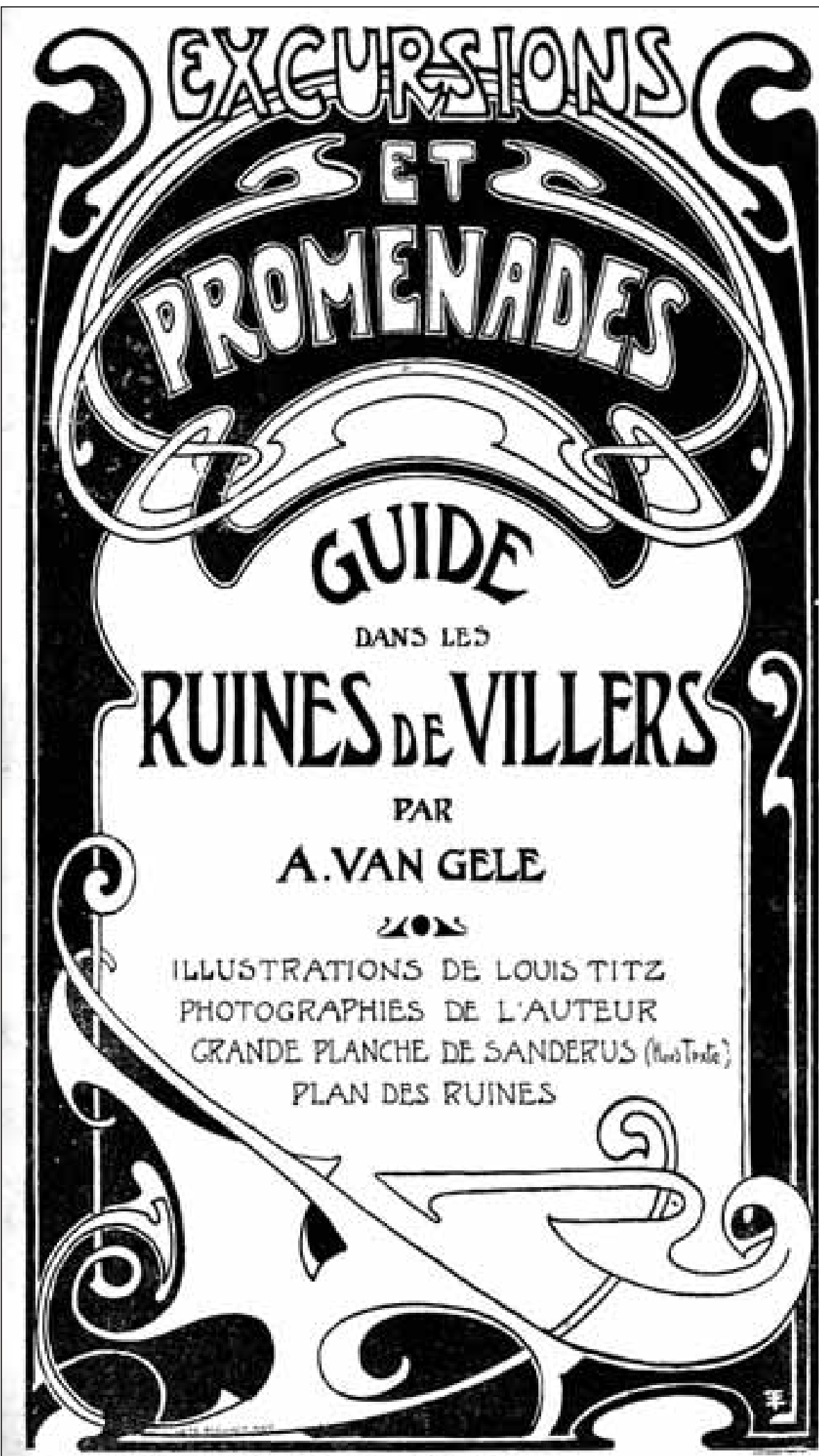

2* EDITION, AVEC UN NOUVEAU PLAN.

III. 6: Art nouveau cover of Guide dans les ruines de Villers by Auguste Van Gele, 1905.

Photo: Author's collection
From that moment, the reconstruction program was accelerated. This provoked a radical reaction and a debate at the Parliament. In August 1907, the minister of public works himself visited Villers and decided to stop the restoration immediately. Only minor "preservation work" would be allowed. Today, the ruins still reflect these conflicting concepts of restoration: some parts are reconstructed and largely restored, while others are authentic but not always intelligible. Nobody won!

A very different ideological approach to the ruins emerged during the First World War. The Germans, who invaded Belgium in August 1914, took over in an active cultural occupation. Art historians and architects started to take inventories of architectural heritage and measurements of historical buildings. The coordinator of the cultural occupation on the Western front was Paul Clemen, a professor at the University of Bonn. One of the first works he entrusted to young scholars was a study of the $C$ istercian abbeys in Belgium. A book was published in Berlin in 1916, with a coherent and comprehensive illustrated chapter on Villers (Zschaler, 1916). The motivation for this work was to prove that the Germans, who had been accused of "barbarism" after destroying the university library of Louvain and bombing the Reims cathedral in 1914, were the first to study the abbeys that the French had destroyed one century earlier. Ideology and cultural destruction!

A new kind of tourism:

Hôtel des Ruines and Touring Club de Belgique

Government restoration projects at Villers also had an important tourist dimension. The fact that the ruins were restored with public money implied some form of benefit for the public. The improvisation of private ownership had to be replaced with organization, information and promotion.

One of the first phases of the restoration involved the former abbey mill, which, as mentioned earlier, was used as a hotel-restaurant. Thanks to major and costly work from 1897 to 1901 , it was turned into a deluxe hotel. At its opening, Hôtel des Ruines offered first-class dining, rooms with bathrooms, gardens and games for children, a darkroom for photographers, covered parking for twelve cars and a petrol station. The interior 
decor was the work of art nouveau decorator Adolphe Crespin, a friend of Charles Licot and the renowned art nouveau architect Paul Hankar. Associating art nouveau with the ruins of an abbey was an interesting approach. It was, of course, in keeping with the fashion in vogue since the Brussels World Exhibition in 1897, as well as the lifestyle of the new elite. But using stylized natural art nouveau forms in a medieval ruin, precisely at the time when the ruin had been cleaned up and cleared of all vegetation, brought a new touch of symbolism and exoticism quite different from the former Romanticism and picturesque chaos. A 1905 guide of the ruins adopted a refined art nouveau design (ill. 6).

In 1907, a memorial in honor of Charles Licot was inaugurated in the cloister. This symbolist bronze bas-relief by Charles Van der Stappen is an allegory of architecture, with a young woman under a trefoil arch, Licot's profile in a medallion, accompanied by two shields with masonic heraldry. At the second international "Congress of the Road" in 1910, Touring Club de Belgique organized the first theatre play in the ruins. Émilie Verhaeren's Le Cloître was a very fitting drama written by one of Belgium's most prominent authors ${ }^{4}$. The minister only allowed one performance because he was angry about setting a precedent $^{5}$. So, an image of a woman was placed in the cloister and monks returned to the abbey, but the woman was an allegory of the architecture, and the monks were actors both expressions of new and living art (ill. 7).

Touring Club de Belgique was founded in 1895 on the model of the Touring Club de France, founded five years earlier. Its main goal was improving quality of the roads, particularly for cyclists. The club offered its members special prices at hotels and garages. It also fought for the simplification of customs procedures, development of emergency infrastructures and road signage, as well as the protection of picturesque landscapes. Four months after its foundation, the club had nearly two thousand members ${ }^{6}$ and had joined a federation of similar national clubs throughout Europe. A new kind of tourist organization was born. From its beginning, Touring Club de Belgique was involved in the ruins of Villers, and later, from 1932 to 1982 , would be the tenant of the ruins. Several guides were published under the patronage of the club.
Trappist monks and

Catholic commemorations in the ruined church

Parfois on aperçoit encore une robe blanche flotter à travers les ruines. C'est un moine de Cîteaux en pèlerinage auprès des restes de Villers-la-Sainte. Le cœur gros d'émotions, il parcourt ces lieux dévastés; il les reconnaît tous car il se retrouve dans une maison de sa famille (... ). Et le moine s'agenouille dans l'église délabrée, là où se sont agenouillés ses pères; il redit, en l'honneur de Notre-Dame, la même psalmodie que ses pères y ont dite. II repart, l'œil humide, mais l'âme vaguement bercée par l'espoir et le désir: «Benigne fac, Domine..., ut aedificentur muri lerusalem. »(Canivez, 1926:93-94)

This excerpt from a history book written by a Trappist monk in 1926 expresses great nostalgia, as well as the secret desire to rebuild J erusalem, i.e., revive the abbey. The revival of the Cistercian order in Belgium had been relatively modest compared to its importance during the Ancien Régime. The continuity was broken since nearly all the nineteenth-century abbeys - two Cistercian and five Trappist ${ }^{7}$ - were new. For all of them, the ruins of Villers were the symbol of the past glory of the Cistercian Order in Belgium. Nevertheless, the return of a Cistercian community to the Villers site was inconceivable now that the site was state property.

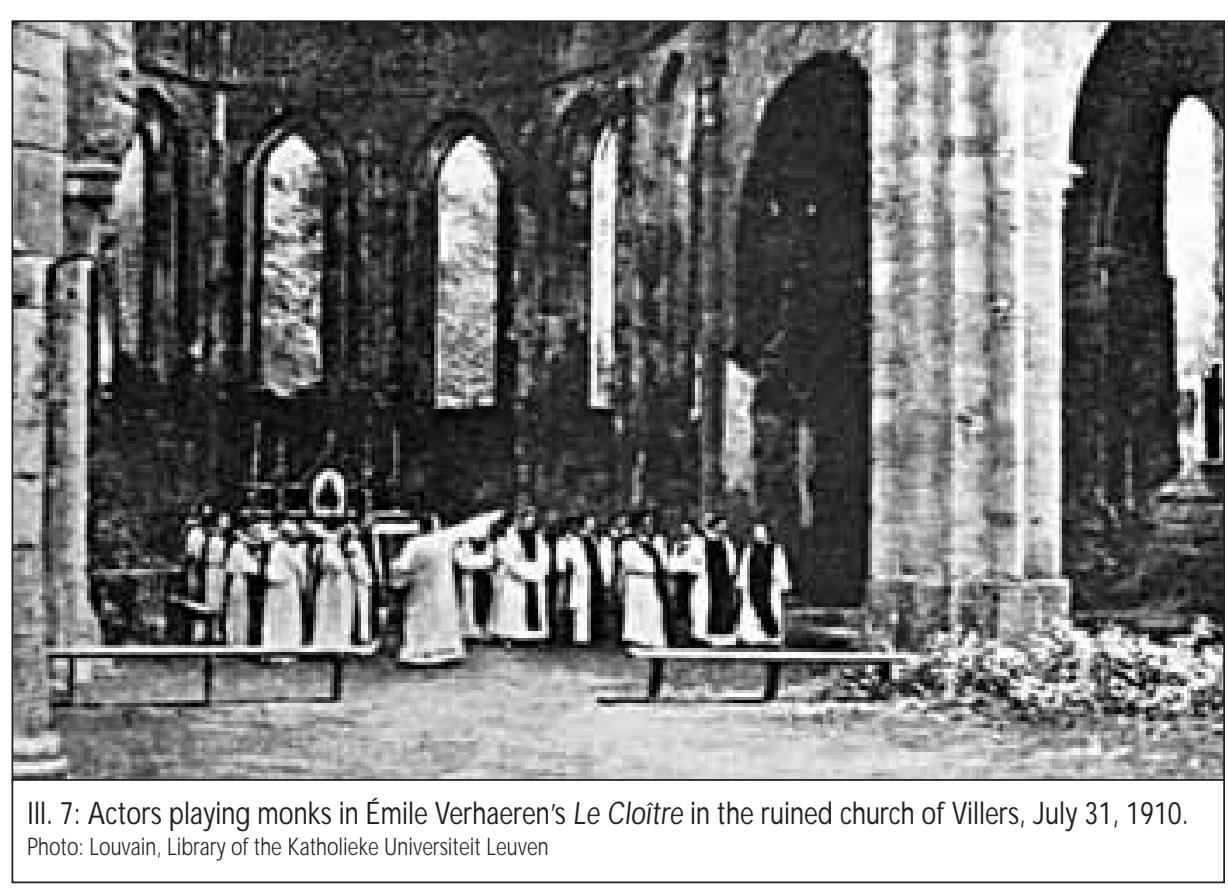

III. 7: Actors playing monks in Émile Verhaeren's Le Cloitre in the ruined church of Villers, J uly 31, 1910. Photo: Louvain, Library of the Katholieke Universiteit Leuven
Orval and Aulne were two other medieval Cistercian abbeys with significant ruins, but not as extensive or impressive as Villers. The former was a private property, while the latter was a public one, which has also been restored with public funds as in Villers. Trappist monks returned to Orval in 1926 and rebuilt a huge neo-Romanesque abbey on the historic site. Work was completed in 1948. Known as the "resurrection" of Orval, this enterprise was a major symbolic endeavor by the Belgian Catholic Church between the two world wars ${ }^{8}$. During that period, the powerful Belgian Church had to adapt to a new, democratic society and mobilized Catholics thanks to new organizations and spectacular identity-building projects. The revival of the abbey of Orval was promoted through the media, and fundraising for the ambitious building project was professionally organized (including four expensive but popular series of stamps).

What better way to promote the Orval monastery project than to use the ruins of Villers? On September 15, 1929, a Pontifical Mass to promote the reconstruction of Orval was held in the church ruins, with white monks from the abbey of Scourmont (ill. 8). A newspaper reported the message of the event: "Man and revolutions pass, but monks live on (... $)^{\prime \prime}$. In an unstable and stressful world, abbeys were perceived as places of peace and stability. For the fist time, real Cistercian monks were back in the church of Villers for a public celebration. 
At the same time, the Church tried to revive memories of the glories of Villers from the thirteenth century, when the abbey's spiritual life had attained a high level of mysticism, and several monks had died in an odor of sanctity ${ }^{10}$. The tomb of one such monk, the blessed Gobert of Aspremont, who died in 1283 , was reconstructed in the corner of the church and the cloister in 1927-1932. However, Villers' greatest glory was not a
Cistercian monk, nor one of the dukes of Brabant who was buried in the church, but a woman from Liège. In 1210, blessed J ulienne of Cornillon had had a vision of Christ, who asked her to promote the cult of the Holy Sacrament. Thanks to her, the feast of Corpus Christi was first instituted in the diocese of Liège and officially extended to the whole Church by the pope in 1256 . J ulienne died in 1258 at Fosses-la-Ville, but

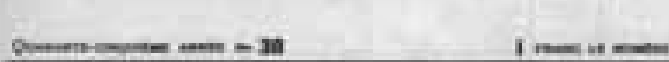 LE PATRIOTE ILLUSTRÉ} MrVUE MEADOMADARE

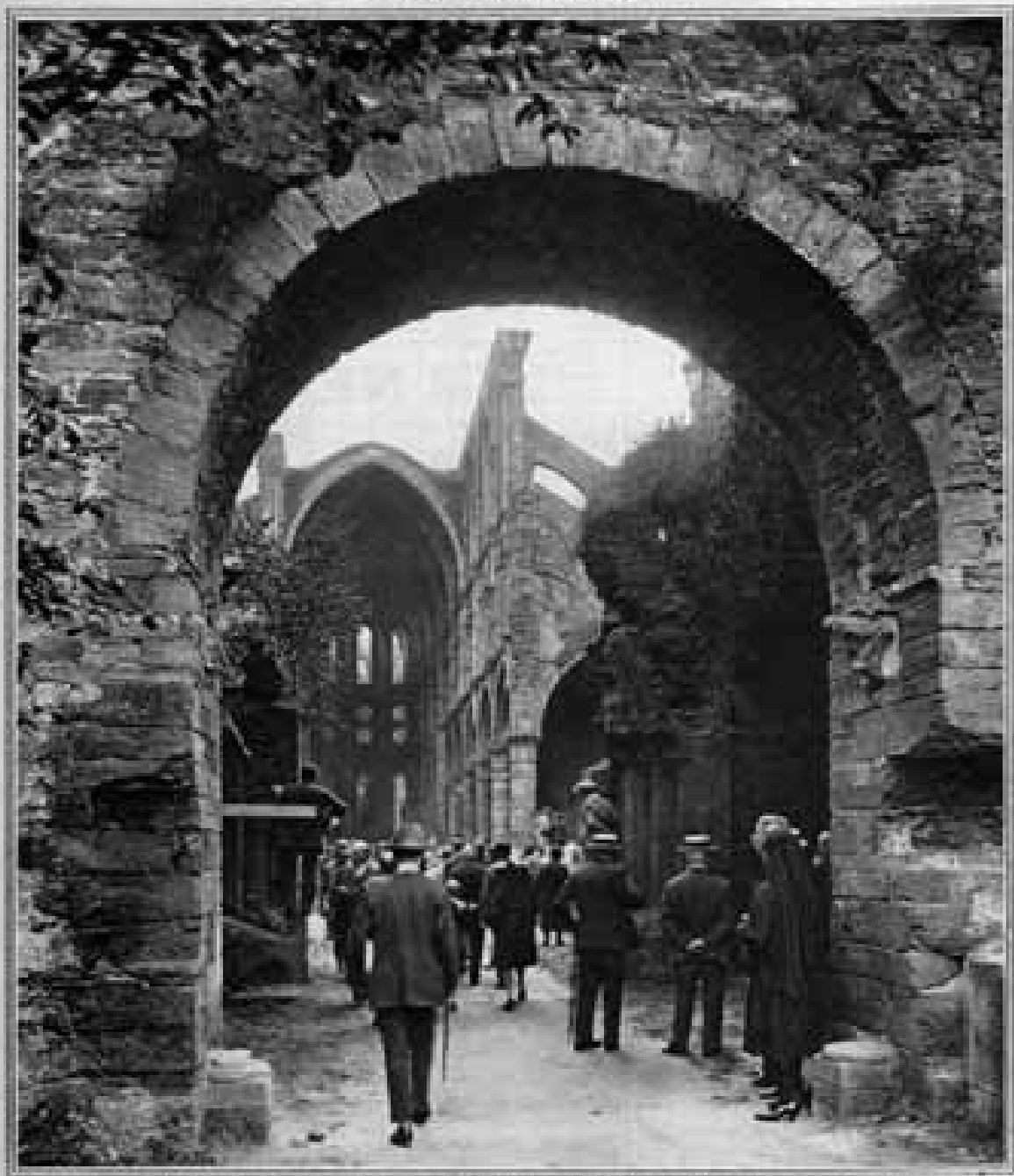

Lhat

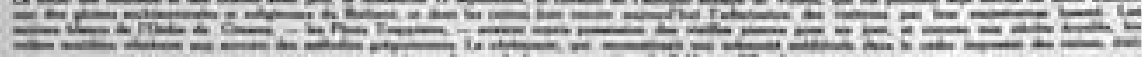

UNE GRANDE SOLENNTE DANS IES RUNES DE LABEAYE DE VILIRS

III. 8: Pontifical Mass at the ruins of Villers to promote the "resurrection" of the abbey of O rval. Cover of Le Patriote illustré, September 22, 1929.

Photo: Author's collection had expressed the wish to be buried in the abbey church of Villers. Finding the relics of J ulienne, who from the nineteenth century was considered a great "Belgian" saint, was an obsession for many churchmen who wanted to revive her cult and perhaps turn Villers into a place of pilgrimage. In 1895, at the request of the bishop of Liège, excavations of her presumed burial site were conducted, but in vain. In 1938, thanks to new information provided by a J esuit who used divination to look for her burial site ${ }^{11}$, new digs were organized in the sanctuary of the church. Again, they were a failure.

After the Second World War, new commemorations were organized in the ruined abbey church. The year 1946 was the 800th anniversary of the foundation of the abbey, as well as the 700th anniversary of the institution of the Corpus Christi feast. On August 25, 1946, a Pontifical Mass was celebrated by Cardinal Van Roey, head of the Belgian Catholic Church, with delegations from all the Trappist and Cistercian abbeys of the country (ill. 9). Two memorials were inaugurated: one in the choir in honor of holly J ulienne, and the other at the entrance of the ruins commemorating the arrival of the first monks in 1146. The Catholic association Honor Brabantiae Villarium had sponsored the latter.

By chance, 1946 also corresponded with the end of the Touring Club de Belgique's lease. Arguing that it was the 800th anniversary and the lease had expired, the Cistercian abbey of Val-Dieu asked the government to return Villers to the Cistercian order. Once again, both the government and the Royal Commission for Monuments and Landscapes politely refused. It was unthinkable to privatize a state property, and the ruins had to remain ruins. They were leased out again to the Touring Club until 1982.

Today, Catholic activities on the site are limited. The main annual event is a mass in the church on the feast of St. Bernard (August 20 ), followed by a benediction of bread and horses on the green in front of the church. The association Animation Chrétienne et Tourisme has long had a cell involved with Villers. The international French-speaking Christian association of guides CASA was present at Villers from 1984 to 1991, but left since it was incompatible with other guide organizations and the theatre activities held in the ruins during the summer. 
Restorations, theatre and cultural marketing

Legal protection for the abbey ruins did not come until very late in the picture. In 1960, the Royal Commission for Monuments and Landscapes called for the listing of the entire site, but only in 1972 did the ruins officially become a protected monument and landscape. Villers could have been listed as early as 1931 - when the law on monuments and sites in Belgium was passed- but successive governments saw no need to protect state property, considering it was not threatened and, in any case, all work would be paid for entirely with public money. Since 1992 , the ruins have been part of the "exceptional heritage of Wallonia", a series of some hundred first class monuments of the region.

From 1914 to 1984 , virtually no restoration or conservation was done at Villers ${ }^{12}$. Plants had grown over the walls and, in some places, caused damage to the masonry. Rainwater was seeping through the vaults of the church. The ruins were in urgent need of repair, as well as better promotion. In 1984, the Ministry of Public Works undertook a new program to consolidate the ruins. The goal was to clean the masonry and fix the ruins without any "visible" additions (Donnay-Rocmans, 1991:62-65). Although there were no stability problems, the structures were systematically reinforced with an expensive and inappropriate technique using grouted steel pins ${ }^{13}$. These works provided the opportunity to conduct serious archaeological research for the first time.

In parallel with the consolidation works, the tenants of the ruins tried to develop new activities ${ }^{14}$. The most spectacular was theatre. Starting in 1987, an annual open-air performance of a play from the classical repertoire has been given ${ }^{15}$. The theatre in the ruins attracts an audience of more than 10,000 people every year and stands out as one of the major cultural summer events in French-speaking Belgium. However, the programs have became too ambitious in order to make a profit: for two months, the theatre takes over the ruins with several stages and all the logistics, to the detriment of all other activities and ordinary visitors. The ruins are (mis)used as a set (ill. 10). A more approp riate cultural event is the prestigious Nuit des Chœurs, a "concert-promenade" featuring choral music in the ruins (ill. 11).

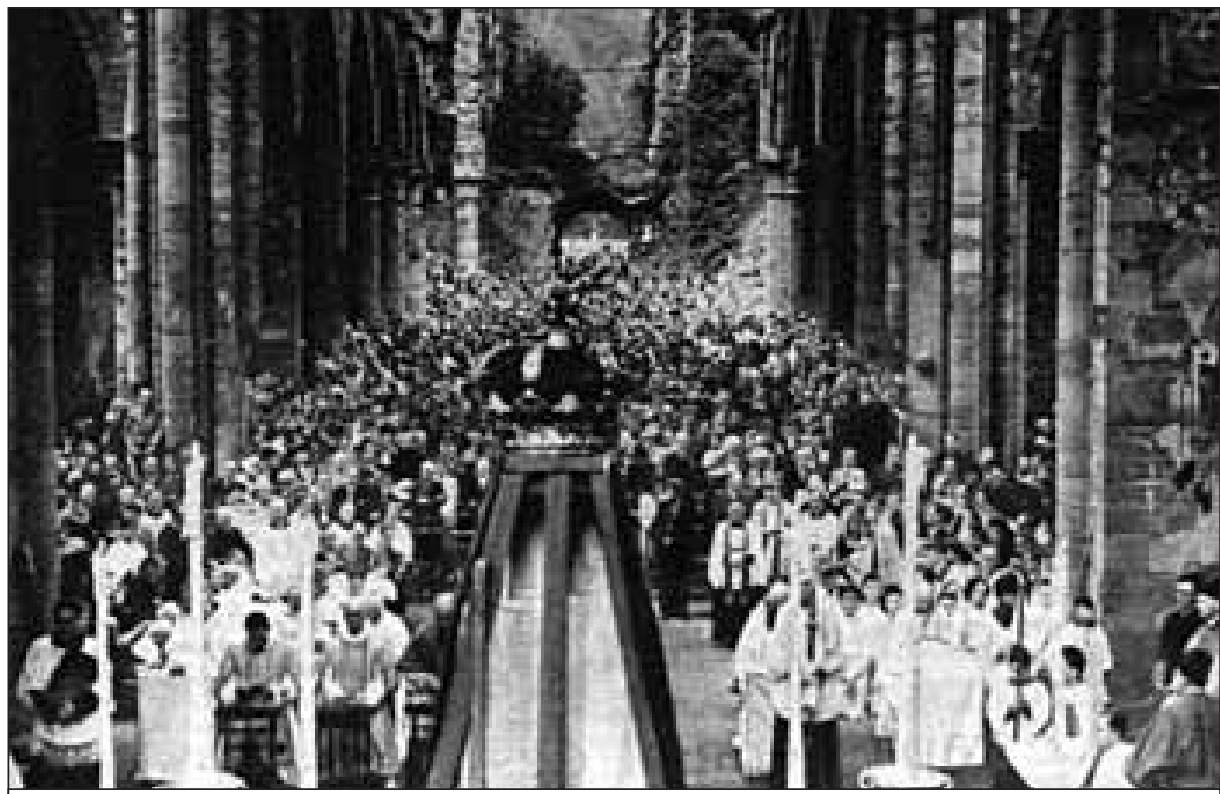

III. 9: Pontifical Mass in the ruins of Villers on the occasion of the $800^{\text {th }}$ anniversary of the foundation of the abbey. Cover of Le Patriote illustré, September 1, 1946.

Photo: Louvain, Katholieke Universiteit Leuven, KADOC

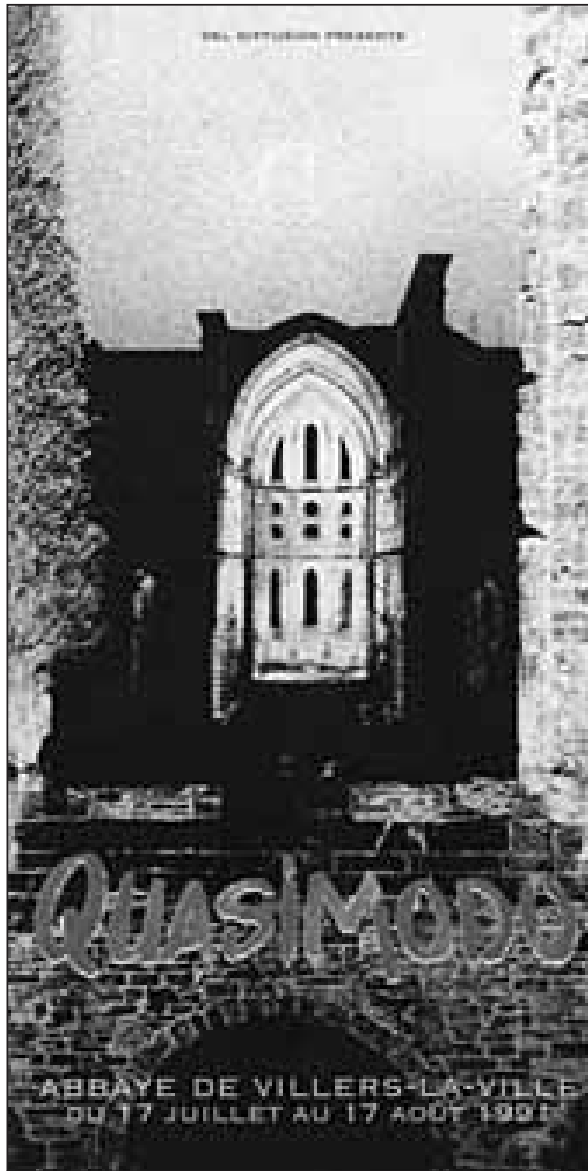

III. 10: The play Q uasimodo, after Notre-Dame de Paris by Victor Hugo, was performed in the ruins in summer 1991. Flyer, by Del Diffusion. Photo: Author's collection

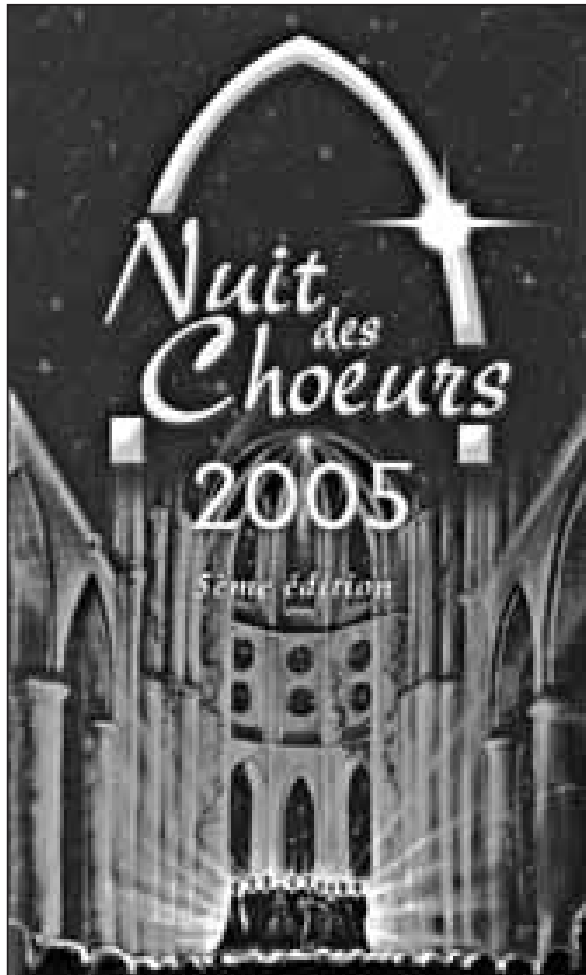

Concert-promenade dans les ruines Abbaye de Villers-la-Ville 25-26-27 Août 2005 $02 / 7360129$ www.nuitdeschoeds.be

III. 11: The Nuit des Chœurs is a prestigious "concert-promenade" for choral music in the ruins. Flyer of the 2005 edition.

Photo: Author's collection 
In order to coordinate the numerous local associations and special projects and promote the ruins to their full potential, a new association was established. Association pour la promotion touristique et culturelle de Villers-la-Ville (APTCV) has run the abbey site since 1992 and does its best to involve as many people as possible through its Friends of the Abbey program, active networking with Wallon cultural and tourist associations, and a varied program of activities. Marketing professionals prepared a strategic report, with the unrealistic ambition of at least doubling the total number of visitors annually from some 40,000 to 100,000 (NCM and Facto, 1995). None of the major infrastructure development proposals in the plan - including a new entrance to the site and an interpretation center- have been acted upon to date, except for a few excavations led by the heritage administration of the Walloon region. Again, 1996 was a year of commemoration: the $850^{\text {th }}$ anniversary of the foundation of the abbey, the 200th anniversary of the dissolution and the $750^{\text {th }}$ anniversary of the feast of Corpus Christy and J ulienne of Cornillon. APTCV organized a scientific symposium, joined European Charter of Cistercian Abbeys and Sites, and started a quarterly historical journal called Villers ${ }^{16}$.

All these efforts tailed off because of the complexity of the "Belgian situation." The main part of the ruins still belongs to the Belgian government, which is responsible for maintenance, while heritage policy, tourism and archeological digs are under the jurisdiction of the Walloon Region, and culture, including education and theatre, the jurisdiction of the French Community. This division makes shared programs and investments almost inconceivable, especially since there is less public money available and growing competition with other tourist suppliers.

\section{"Stones pray"}

In the two centuries since the takeover of abbey, perceptions of the ruins have varied: Romanticism and picturesque, Catholicism and monasticism, history and archaeology, the Middle Ages, etc. These changing perceptions have themselves become part of the history and heritage of the site, leaving their mark on the monument as choices were made, in particular during restorations.

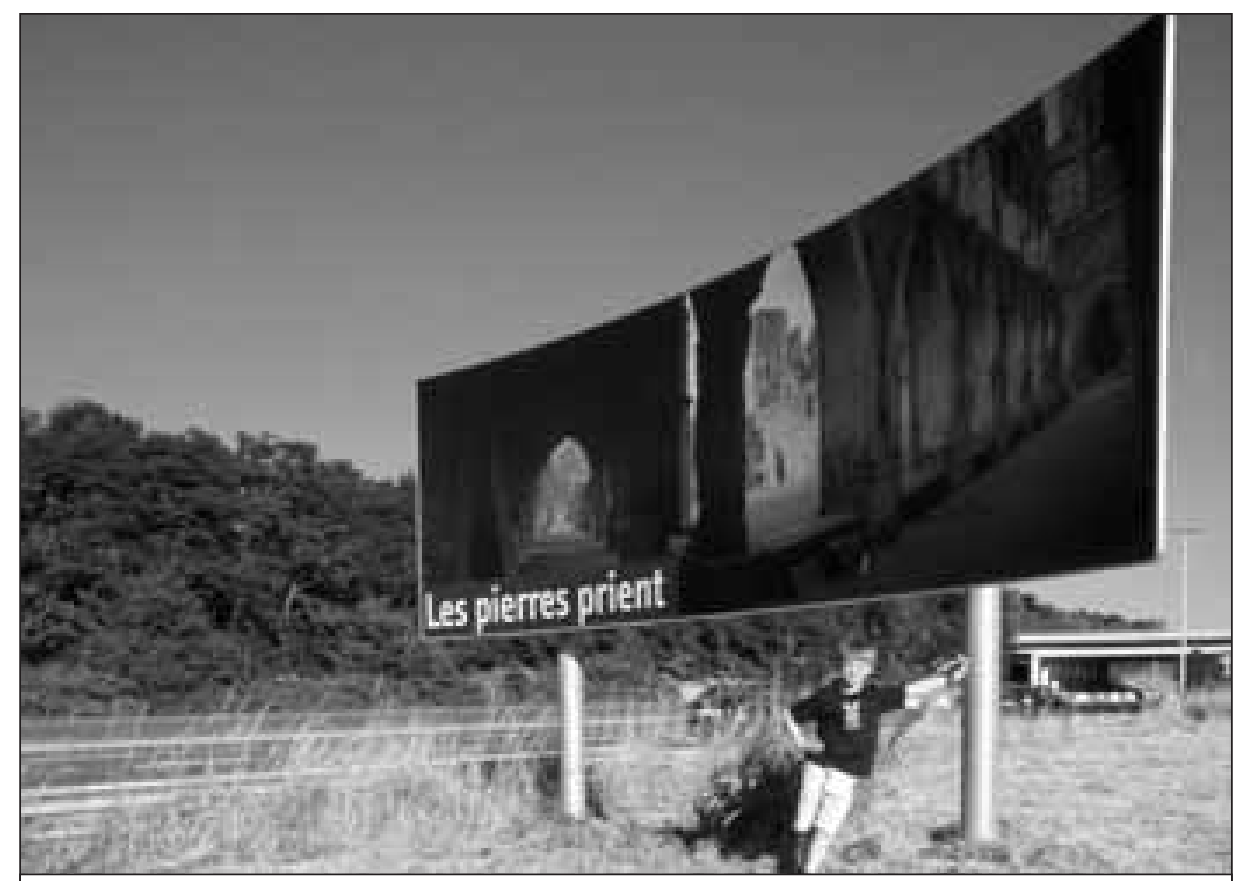

III. 12: "Les pierres prient" along the E411 motorway, Louvrange interchange. Photo: @ THOC, J une 2005

There has always been an economic dimension to the site as well, from the sale of the abbey and its building materials to the most recent forms of cultural tourism and marketing. The acquisition by the government in 1892 clearly saved the ruins. Both major public restoration campaigns were long term investments and provided returns in the form of new tourism developments. For heritage to be maintained and survive, its only hope is to generate money, attract tourists and provide jobs. A site such as Villers is considered as a business and must be marketed as a product that delivers what people are looking for.

Therefore, it is critical to determine what people today expect from a ruined church. A survey conducted in 1995 revealed that nearly all visitors interviewed were touched by the magic, mystery and grandeur of the site: "It is a magnificent place... a magnetic place... that has a special evocative power all its own..." Most people were sensitive to the blend of sacred and profane, but many found the sacred character "sad, gloomy and lifeless" (NCM and Facto, 1995:15). This means that since the explicit religious dimension of the abbey disappeared, it has become more difficult to experience its sacred character in a positive way. Visitors feel that the site carries a spiritual power from centuries past - something that sets it apart from other medieval ruins (castles, for example)- but cannot identify it with precision.
A few months ago, new tourist road signs were installed along the motorways in Wallonia. The campaign explicitly neglects to mention the names of the featured sites, but combines a color photo with a hip and sometimes ambiguous slogan. The ruins of Villers were showcased on one panel bearing a large, somber photograph of the arches of the cloister galleries facing the church ruins, with the catchphrase Les pierres prient -- "Stones pray" (ill. 12). This new-age-tinted slogan accurately reveals today's perceptions of the monastic ruin, where neither monks nor visitors pray. With the monks long gone and modern-day visitors little interested in prayer, marketers promote the alluring sacred character of the site by giving the stones the power to pray. And old stones are associated with heritage in general and ruins in particular.

It is impossible to imagine how the church ruins will be perceived in another century or two. The only thing that is certain is that they will continue to attract visitors.

Thomas Coomans is senior research fellow at Katholieke Universiteit Leuven (Belgium), KADOC: Research and Documentation Center on Religion, Culture and Society (www.kadoc.kuleuven.ac.be). 
Notes

1 For Monograph of the abbey, see: Coomans, Thomas (2000).

2 About the Royal Commission, see: Stynen, Herman (1998), De onvoltooid verleden tijd. Een geschiedenis van de monumenten- en landschapszorg in Belgë 1835-1940, Brussels, Stichting Vlaams Erfgoed; Coomans, Thomas (2003), "Restauration et conservation", in Dictionnaire de l'architecture en Belgique de 1830 à nos jours, Anne Van Loo (ed.), Antwerp, Fonds Mercator, p. 274-280.

3 For more details, see: Coomans, Thomas (1990).

4 The play had first been performed in Brussels and Paris in 1900, see: Verhaeren, 1909

5 Thanks to the intervention of the king, repeat performances were finally allowed on J uly 31 and August 7, 1910. Brussels, AGR, Travaux publics, Ponts et Chaussées, Bâtiments civils, 196.

6 In 1899, there were 20.000 members; in 1911, 62.000. See: X (1955), Memorial du Royal Touring Club de Belgique 1895-1955, Brussels, p. 124-125 and 238.

7 Cistercian abbeys of St. Bernard at Bornem (1836) and Val-Dieu (1840); Trappist abbeys of Westmalle (1794-1814), St. Sixtus at Westvleteren (1831), Achel (1838-1845), Scourmont at Forges-les-Chimay (1850) and St. Remy at Rochefort (1885).

8 Several contributions in the recent reference work: Orval 1926-1948. Entre restauration et résurrection (2001), Claude Soetens (ed.), Louvain-la-Neuve, Archives du monde catholique.

9 Les hommes, les révolutions passent, mais les moines restent (...), in: Le Patriote illustré. Revue hébdomadaire (1929), 45 th year, $n^{0} 38$, September 22, 1929, p. 1201-1202.

10 It is important to note the relations between the abbots of Villers and the famous German mystic Hildegard of $B$ ingen, as well as the prominent role the abbots of Villers played in the development of the beguinage movement and the feminine branch of the Cistercian Order in the diocese of Liège and the duchy of Brabant.

11 Father Lepers S.J . was an expert in "radiésthésie", i.e., divination based on the detection of radiation emitted by various bodies.

12 Many projects were proposed between the wars, but only a few restoration campaigns would be carried out for the Ministry under the direction of architect Herman Lemaire, between 1936 and 1938.

13 "Reticoli cementato" of Fondedile.

14 In 1982, the Touring Club decided not to renew the lease, which was taken over until 1992 by the Syndicat d'Initiative et de Tourisme de Villers-la-Ville in a joint venture between the commune of Villers-la-Ville and the province of Brabant.

15 Barrabas of Michel de Ghelderode, Torquemada and Quasimodo after Victor Hugo, Roméo et J uliette by William Shakespeare,
Cyrano de Bergerac by Edmond Rostand, Athalie of J ean Racine, Faust after Goethe, Salomé of Oscar Wilde, etc.

16 After 29 quarterly issues, the journal ceased publication in J anuary 2004 . It should be continued as a annual publication.

\section{References}

Andries, Pool, and Willem Aerts (1993), Camera Gothica. Gothic church architecture in the 19th century European photography, Antwerp, Province of Antwerp.

Antoine, François (1996), La vente des Biens Nationaux dans le Département de la Dyle, doctoral thesis, Faculty of Philosophy and Letters, Université Libre de Bruxelles.

Bueger-Van Lierde, Françoise de (2002), «La traversée du site de l'abbaye de Villers par la voie de chemin de fer: tracé, réactions et conséquences », Villers, $n^{0} 22$, $2^{\text {ième }}$ trimestre, p.12-29.

Canivez, J oseph-Marie (1926), L'Ordre de Cîteaux en Belgique, des origines (1132) au $X X^{m e}$ siècle, Aperçu d'histoire monastique, Forges-les-Chimay, Abbaye de Scourmont, p. 93-94.

Coomans, Thomas (1990), Abbaye de Villers. Histoire des ruines (1796-1984). Les interventions du Ministère des Travaux publics en vue de leur sauvegarde, Louvain-la-Neuve (coll. "Publications d'Histoire de l'Art et d'Archéologie de I'Université Catholique de Louvain", 72).

Coomans, Thomas (2000), Villers-en-Brabant, Construction, configuration et signification d'une abbaye cistercienne gothique, BrusselsBrecht, Racine and Cîteaux, Commentarii cistercienses (coll. "Studia et documenta", 11).

Coomans, Thomas, and Tom Verschaffel (2003), «Victor Hugo et la Belgique: regards croisés sur le patrimoine médiéval», in Roland Recht (ed.), Victor Hugo et le débat patrimonial. Actes du colloque organisé par I'Institut national du Patrimoine, Paris, Somogy, p. 204-225.

Coulon, Émile (1878), «L'église de l'ancienne abbaye de Villers », Bulletin des Commissions royales d'Art et d'Archéologie, 17, p. 259-321.

De Cloet, J ean (1825), Voyage pittoresque dans le Royaume des Pays Bas..., vol. 2, Brussels.

De Cloet, J ean (before 1830), Châteaux et monumens des Pays Bas..., vol. 2, Brussels.

De Maeyer, J an (2000), "The Neo-Gothic in Belgium: Architecture of a Catholic Society", in De Maeyer, J an and Luc Verpoest, Gothic Revival. Religion, Architecture and Style in Western Europe 1815-1914, Louvain, University Press, p. 19-34 (coll. "KADOC Artes", 5).

De Maeyer, J an (ed.) (1988), De Sint-Lucasscholen en de neogotiek, 1862-1914, Louvain, University Press (coll. "KADOC-Studies", 5).

Donnay-Rocmans, Claudine (1991), "L'abbaye de Villers-la-Ville: un exemple de restauration / conservation d'une ruine romantique», in Faut-il restaurer les ruines? Actes du colloque de la Direction du Patrimoine, Mémorial de Caen, novembre 1990, Paris (coll. «Entretiens du Patrimoine», 3).

Fierens-Gevaert, Hippolyte (1900), «Les restaurations en Belgique », La Chronique des Arts et de la Curiosité. Supplément à la Gazette des Beaux-Arts, Paris, November 17.

Gens, Eugène (1849), Ruines et paysages en Belgique, Brussels, ed. A. J amar.

Hugo, Victor (1952) [1862], «Le couvent, fait historique », in Les Misérables, Maurice Allem (ed.), Paris, Bibliothèque de la Pléiade.

Licot, Charles, and Émile Lefèvre (1877) [1883 and 1929], Abbaye de Villers-la-Ville de l'Ordre de Cîteaux. Description des ruines avec plans et dessins, Brussels.

NCM \& Facto (1995), Un projet culturel et touristique pour le site de l'abbaye de Villers-la-Ville, unpublished, $39 \mathrm{p}$.

Pil, Lut (1993), «Pour le plaisir des yeux». Het pittoresque landschap in de Belgische kunst: 19de-eeuwse retoriek en beeldvorming, Louvain-Apeldoorn, Garant Uitgevers.

Rodenbach, Constantin (1850), L'abbaye de Villers (de l'Ordre de Cîteaux), Brussels, Imprimerie et typographie des Beaux-Arts.

Schayes, Antonin (1840), Essai sur l'architecture ogivale en Belgique, mémoire couronné par l'Académie de Bruxelles, Brussels, p. 69-72.

Spelman, Henry (1846), The History and Fate of Sacrilege, $4^{\text {th }}$ ed., London, Hodges.

T.J . (1839-1840), «Excursions pittoresques. Environs de Bruxelles», La Renaissance, chronique des beaux-arts et des lettres, Brussels.

Tollebeek, J o (1998), "Historical Representations and the Nation-State in Romantic Belgium (1830-1850)", J ournal of the History of Ideas, vol.59, n² 2, p. 329-353.

Tordoir, J oseph (2002), «Biens noirs d'Église: problèmes de conscience... et malédictions », in Thomas Coomans (ed.), La Ramée. Abbaye cistercienne en Brabant walIon, Brussels, ed. Racine.

Verhaeren, Émile (1909), Deux drames: Le Cloître, Philippe II, Paris, Mercure de France.

Vries, Aart de (1999), "Ruïnes: restauratie en antirestauratie", in De Maeyer, Jan and Wim Denslagen, Herman Stynen, Wies van Leeuwen, Luc Verpoest (ed.), Negentiende-eeuwse restauratiepraktijk en actuele monumentenzorg, Handelingen van het NederlandsVlaams symposium, Leuven 13-14 september 1996, Louvain: University Press, p. 176-187, especially (coll. "KADOC Artes", 3).

Willaumez, Marie-France (2002), «Au fil des guides touristiques: la vie dans les ruines de Villers au XIXe siècle », Villers, $n^{0} 22,2^{\text {ième }}$ trimestre, p. 4-11.

Zschaler, Willy (1916), "Die Abtei Villers", in Clemen, Paul and Cornelius Gurlitt, Die Klosterbauten der Cistercienser in Belgien, Berlin, Der Zirkel, p. 66-131. 